1969

\title{
Damage Measures and Economic Rationality: The Geometry of Contract Law
}

Robert Birmingham

University of Connecticut School of Law

Follow this and additional works at: https://opencommons.uconn.edu/law_papers

Cart of the Contracts Commons

\section{Recommended Citation}

Birmingham, Robert, "Damage Measures and Economic Rationality: The Geometry of Contract Law" (1969). Faculty Articles and Papers. 374.

https://opencommons.uconn.edu/law_papers/374 


\section{HEINONLINE}

Citation:

Robert L. Birmingham, Damage Measures and Economic Rationality: The Geometry of Contract Law, 1969 Duke L.J. 49 (1969)

Content downloaded/printed from $\underline{\text { HeinOnline }}$

Thu Jun 21 14:31:20 2018

-- Your use of this HeinOnline PDF indicates your acceptance of HeinOnline's Terms and Conditions of the license agreement available at https://heinonline.org/HOL/License

-- The search text of this PDF is generated from uncorrected OCR text.

-- To obtain permission to use this article beyond the scope of your HeinOnline license, please use:

\section{Copyright Information}

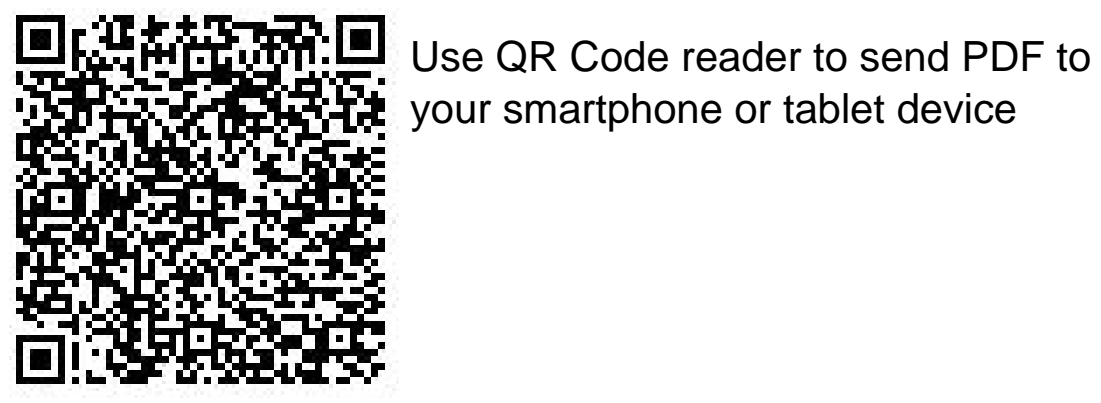




\title{
DAMAGE MEASURES AND ECONOMIC RATIONALITY: THE GEOMETRY OF CONTRACT LAW
}

\author{
ROBERT L. BIRMINGHAM*
}

"The belief that probably causes the most difficulty in the field of public policy is this: if two people engage in a transaction and one of them is seen to gain thereby, it must follow that the other has lost."

- [D. Paarlberg, Great Myths of Economics 27 (1968)]

The question of damage measures presented by the conscious decision of a promisor to breach a losing contract raises one of the most perplexing conceptual problems in contract law. Recognizing the present inability of the courts rationally to resolve the problem, as illustrated by the opposing decisions in Groves v. John Wunder Company and Peevyhouse v. Garland Coal and Mining Company, the author undertakes to examine the premises of contract law' with a fresh perspective-economic analysis.

\section{INTRODUCTION}

S. J. Groves \& Sons Company and John Wunder Company excavated and sold sand and gravel from neighboring sites in suburban Minneapolis. In 1927 Groves Company leased its tract to Wunder for a term of seven years. Exploitation of its deposits of these materials was intended. Wunder paid Groves Company $\$ 105,000$ and undertook to leave the property "at a uniform grade, substantially the same as the grade now existing at the roadway . . . on said premises ...."Wunder removed only the best gravel, leaving the land uneven and above the level of the roadway. In an action for breach of contract brought by Frank M. Groves, assignee and successor of Groves Company, the trial court found that performance by Wunder would require removal from the premises of 288,495 cubic yards of overburden at a cost of at least $\$ 60,000$. It

\footnotetext{
* Assistant Professor of Law, Indiana University School of Law. A.B. 1960, LL.B. 1963, Ph.D. 1967, Pittsburgh; LL.M., Harvard, 1965.
} 
further determined that if the defendant had fulfilled his obligations the value of the property at the expiration of the lease would have been only $\$ 12,160$. The trial court awarded the plaintiff this sum, together with interest. The plaintiff appealed.

In 1954 Willie and Lucille Peevyhouse leased their Oklahoma farm to the Garland Coal and Mining Company for a term of five years. Strip mining operations were contemplated. Garland agreeu to carry out certain remedial and restorative work at the end of the lease period, but failed to do so. The Peevyhouses sought damages of $\$ 25,000$ for breach of contract. Expert witnesses placed the cost of performance at about $\$ 29,000$. On the other hand, the defendant offered evidence that performance would increase the market value of the property by only about $\$ 300$. The trial judge instructed the jury to find for the plaintiff but gave little guidance concerning the appropriate measure of damages. The jury returned a verdict for $\$ 5000$, and judgment was entered for this amount. Both parties appealed.

Review of these parallel disputes by the supreme courts of Minnesota and Oklahoma yielded sharply contrasting conclusions. Judge Stone, writing for a plurality of the court in Groves v. John Wunder Co.,' summarily denounced the appealed judgment: "Defendant's breach of contract was wilful. There was nothing of good faith about it. Hence, that the decision below handsomely rewards bad faith and deliberate breach of contract is obvious. That is not allowable." Noting that Minnesota precedents did not decisively resolve the controversy, he examined and rejected as unpersuasive other authorities introduced to support affirmance. Bigham v. Wabash-Pittsburgh Terminal Ry. Co., ${ }^{3}$ relied on by the defendant to demonstrate that recovery by the plaintiff should be limited to the reduction in the value of the property caused by default, i.e., out-of-pocket loss, was dismissed as mistakenly applying to a case involving breach of contract a remedial standard applicable only in tort actions. ${ }^{+}$The doctrine of economic waste was

' 205 Minn. 163, 286 N.W. 235 (1939). The case has been extensively discussed. See Annot.. 123 A.L.R. 515 (1939); 40 ColUM. L. Rev. 323 (1940); 25 CoRNELL. L.Q. 287 (1940); 53 HARV. L. REV. 138 (1939); 34 lLL. L. REV. 501 (1939); 24 MiNN. L. REV. 114 (1939).

$=205$ Minn. at 165,286 N.W. at 236.

223 Pa. 106, 72 A. 318 (1909).

+A tort action is possible if $A$ contracts with $B$ for the right to remove gravel and mistakenly excavates on $C$ 's land, leaving it in an ungraded condition. Here $C$ could recover his "loss." the 
held relevant only in other contexts: "The waste avoided is only that which would come from wrecking a physical structure, completed, or nearly so, under the contract. The cases . . . go no further."' The court concluded that to award the cost of performance could not be considered unconscionable enrichment to the owner "[w]hen the result is but to give one party to a contract only what the other has promised ...." It remanded for retrial, commenting that the cost of performance might be substantially less than the court below had contemplated because removal from the premises of large quantities of overburden could prove unnecessary.

In a vigorous dissent, Justice Olson argued that the sole problem confronting the court was computation of the sum which would "adequately compensate plaintiff for his loss caused by defendant's failure to render performance." He reasoned that to award damages of $\$ 60,000,500$ percent more than the property properly graded was worth, was to give the owner something neither contemplated nor contracted for. ${ }^{8}$ His conclusion that the judgment of the trial court should be affirmed was supported by one other justice. Two of the seven members of the court did not participate in the decision.

Explicitly repudiating Groves, the majority opinion in Peevyhouse v. Garland Coal \& Mining Co. ${ }^{9}$ limited recovery by the plaintiffs to $\$ 300$, the increase in the value of their farm which would have resulted from performance by the defendants. Asserting that "the contract provision breached was merely incidental to the main purpose in view," the court ruled: "[W]here the economic benefit which would result to lessor by full performance of the work is grossly disproportionate to the cost of performance, the damages

difference in the value of the land hefore and after B*s removal of the gravel. Suppose, however, that $B$ had no contract with anyone and knew that $C$. the owner of rich gravel deposits, was au ay for the year. If B deliberately removed the gravel from C"s land and left it in an unrestroed condition. ( would be able to recover his "loss" as in the hypothetical case above: but he probably would be awarded punitive damages as well. Thus, where the tort is willful, recovery may well equal the "cost of performance" award in the Groves case.

205 Minn. at 171. $286 \mathrm{~N}$.W. at 238.

$l_{1}$ is arguable that the expenditure of large sums for marginal economic purposes, as was contemplated by the award of damages amounting to the cost of performance. logically falls uithin the proseription of the doctrine of economic waste.

(Id. at 170, 286 N.W. at 238.

Id. at 173, 286 N. W. at 239.

Id. at 176. $286 \mathrm{~N}$. H, at 241 .

382 P.2d 109 (Okla. 1962), aff"d on rehearing. 382 P.2d 116 (Okla. 1963), c'crt, denied, 375 U.S. 906 (1963). The case was noted in 49 lows L. Rrv. 597 (1964).

382 P.2d at 114. 
which lessor may recover are limited to the diminution in value resulting to the premises because of the non-performance." Arguments of equity relied on in Groves were reversed in Peevyhouse. The court reasoned that the "cost of performance" rule would give the landowners greater benefit from the breach than they could have realized from full performance. A recovery of nine times the value of the land was characterized as "unconscionable and grossly oppressive damages, contrary to substantial justice."12

Four of the nine members of the court disagreed. A dissenting opinion repeated much of the reasoning that had prevailed in Groves, stressing that "defendant's breach of the contract was wilful and not in good faith." ${ }^{\prime 3}$ On rehearing the division of the court remained unchanged.

Neither decision appears adequately to resolve the problems raised by the dispute which fostered it. In each case the courts were sharply divided. Both of the solutions ultimately adopted appear extreme. The trial courts had achieved compromises: In Groves the plaintiff was first awarded the value of the land rather than the increase in value which would have resulted from performance by the defendant; in Peevyhouse the initial judgment was so obviously intermediate between the claims of the parties that both appealed.

The unlikelihood of frequent occurrence of disputes resulting from situations similar to that discussed, termed "unrealistic"1/4 in the Peevyhouse opinion, precludes justification of efforts to achieve a more satisfactory solution on grounds of the needs of parties potentially involved. As will be shown, however, the difficulties encountered are not products of isolated anomalies but rather manifestations of a problem of fundamental significance to the structuring of remedial policies. Exploration of the implications of this problem should prove profitable. Of greater importance, however, is the opportunity offered by the inadequacy of the reasoning of the courts to introduce economic tools which permit examination of the premises of contract law from a fresh perspective.

\footnotetext{
"Id.

${ }^{12} I d$. at 113. The bulk of this analysis occurs in conjunction with court application of state statutory law. See OKLA. STaT. tit. 23, $\$ 96,97$ (1961). Although the court considered this legislation "controlling," it would appear to have had little impact on the decision. See 382 P.2d at 119.

1382 P.2d at 115.

"Id. at 113.
} 


\section{The Contract Curve}

\section{Geometry}

The basis of contract, i.e., the possibility of individual benefit through exchange, may be simply demonstrated..$^{15}$ Plot quantities of two goods, e.g., eggs and butter, along the horizontal and vertical axes in figure 1 . Then any point within either quadrant or along an axis will denote a unique combination of the two goods. Associate each quadrant with an individual. Offered a choice between combinations of goods represented by any two points within this quadrant, an individual will either prefer one to the other or be indifferent as to which he obtains. The locus of all combinations of goods from which he derives equal satisfaction is called an indifference curve. Assuming infinite divisibility of both goods, each point along or between the axes will be on an indifference curve. Such a curve will usually be convex to the origin because acquisition of increasing quantities of an item will normally render it less valuable in terms of other goods possessed in unchanging amounts.

In figure 1 three indifference curves are drawn for each of two potential traders, $\mathrm{X}$ and $\mathrm{Y}$. Assume that prior to exchange both are located at point $a$, so that $X$ possesses an amount $O_{x}$ a of eggs and no butter while $Y$ has no eggs but an amount $O_{y}$ a of butter. They will be on indifference curves $X_{1}$ and $Y_{1}$ respectively. If the possibility of satiation is disregarded, the welfare of each individual can be increased through movement to an indifference curve with a higher subscript; such a shift can make available more of one good without reducing the supply of the other.

Prospective advantage from exchange can be demonstrated by a combination of the two parts of figure 1. In figure 2, part (b) of figure 1 has been rotated 180 degrees and superimposed on part (a). The dimensions of the resulting rectangle, known as an Edgeworth box, ${ }^{16}$ are the combined endowments of the two individuals. Before trade occurs both remain at point $a$, the northwest corner; their welfare levels are those associated with indifference curves $X_{1}$ and $Y_{1}$ respectively. Through exchange the parties may move from point $a$ to any point within the rectangle or along its edges. A shift to any

\footnotetext{
"See generally. Shapley \& Shubik, Concepts and Theories of Pure (ompetition, in 1.SSAYs in Matilimatical licononics in Honor of Oskar Morgenstern 63 (M. Shubik ed. 1967).

in See F. Edgeworth. Mathematical. Physics (1881).
} 


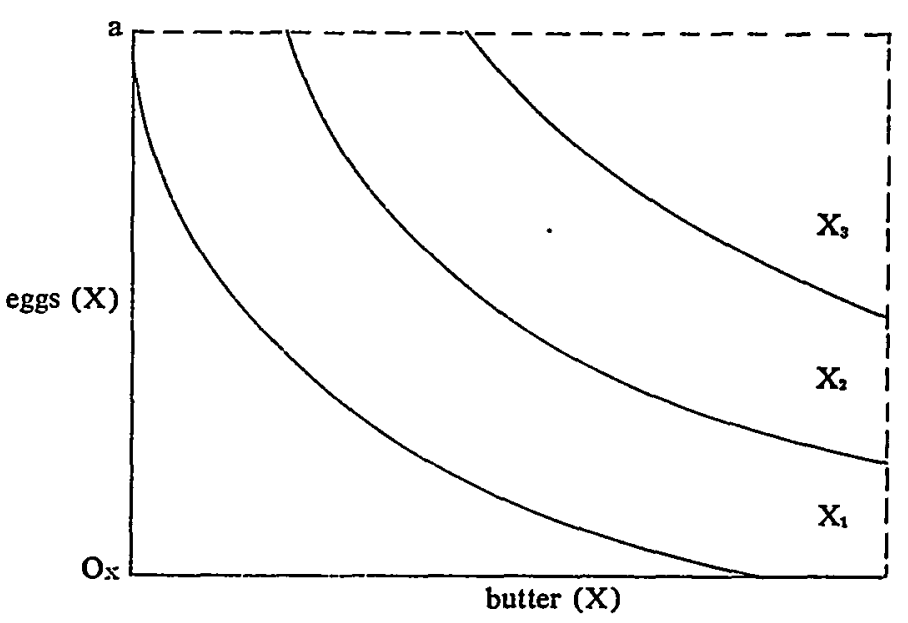

(Part a-Individual X)

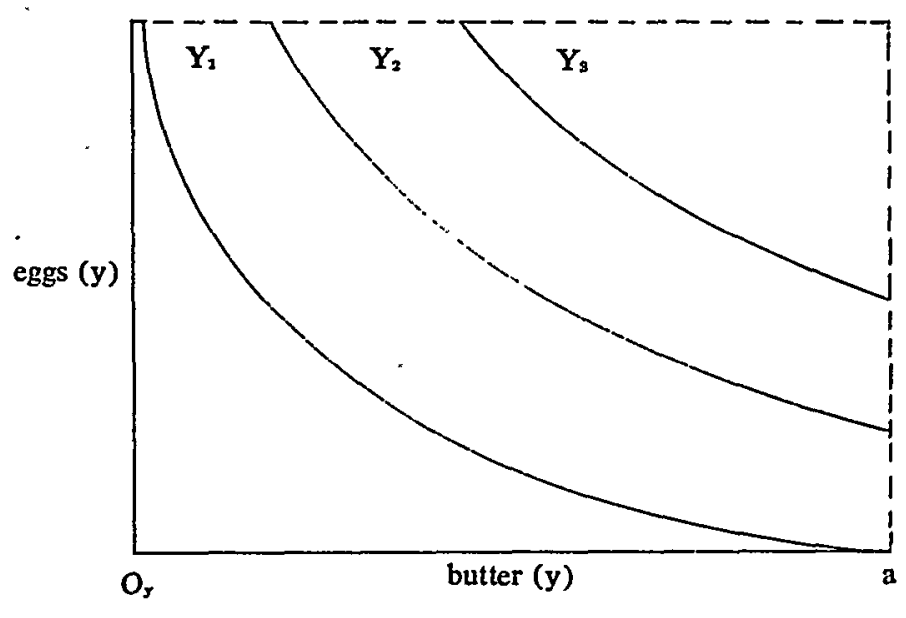

(Part b-Individual Y)

Figure 1 
position between $X_{1}$ and $Y_{1}$ will benefit each individual through placing him on a higher indifference curve: If point $b$ is selected, for example, the welfare levels of the traders are increased to those associated with indifference curves $\mathrm{X}_{2}$ and $\mathrm{Y}_{2}$.

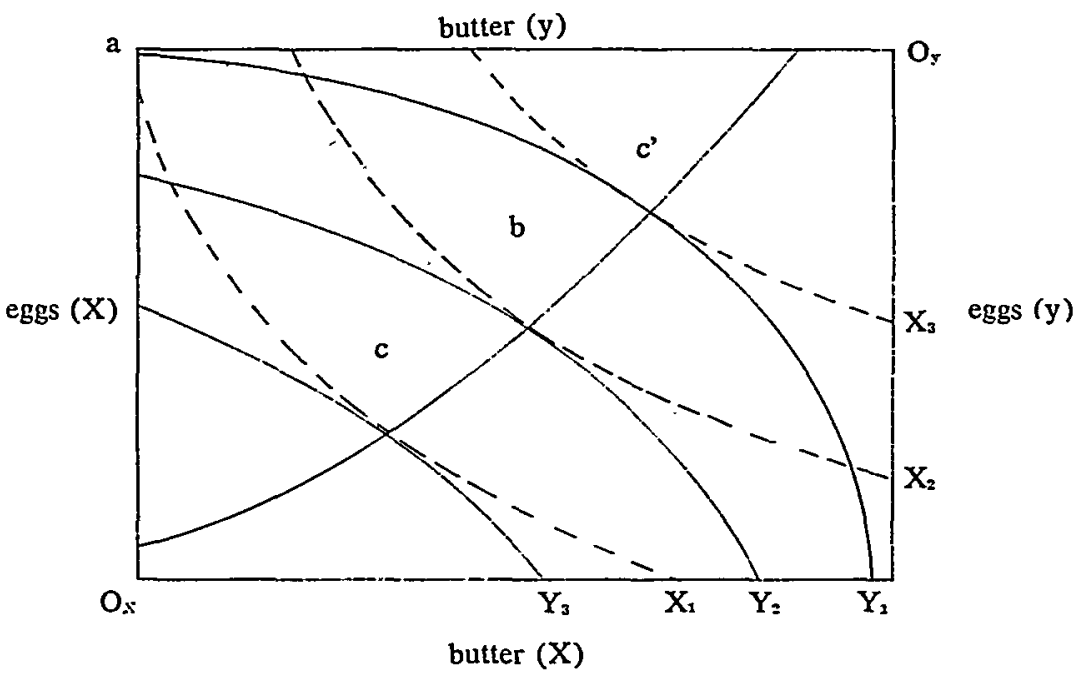

Figure 2

A position is Pareto optimal when movement from it cannot benefit one individual without injuring another. ${ }^{-}$Disregard the impact of the actions of the potential traders on other members of the community. Then in figure 2 only points along the line $O_{\backslash} \mathrm{cbc}^{\prime} \mathrm{O}_{y}$, connecting all tangencies between the two sets of indifference curves, satisfy this condition. The nonoptimality of positions not on this line, called a contract curve, is demonstrated in figure 3. Here a point e not on contract curve $O$ 、 dd ${ }^{\circ} \mathrm{O}$, has been arbitrarily selected;

The concept was lirst isolated by the economst whose name it bears. "I lonvider any particular position and suppose that a lery small mone is made [lrom it]. . . [I hen il the well-being of all the individuals is increased. it is evident that the new position is more advantageous lor each one of them: vice versal it is less so it the well-being of all the individuals is diminished. The "cll-being of some mat remain the same without these conelusions being affected. But if, on the other hand. the small move increases the well-being of certain individuals. and dininishes that of others. it ean no longer be said that it is atdvantigeous in

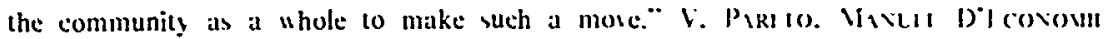

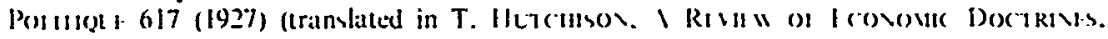
1870-1929. at $225(1953))$. 
the indifference curves on which it lies, $X_{\mathrm{e}}$ and $\mathrm{Y}_{\mathrm{e}}$, have been drawn in. $X$ will benefit if the shift resulting from trade moves him to an indifference curve located northeast of $X_{e}$, while $Y$ will gain if exchange causes movement to the southwest of $Y_{e}$. The shaded area between the two indifference curves, lying to the northeast of $X_{\mathrm{e}}$ and to the southwest of $Y_{e}$, is a region of profit to both individuals. Such an area will exist for all points not on $\mathrm{O}_{x} \mathrm{dd}^{\prime} \mathrm{O}_{\mathrm{y}}$ '.

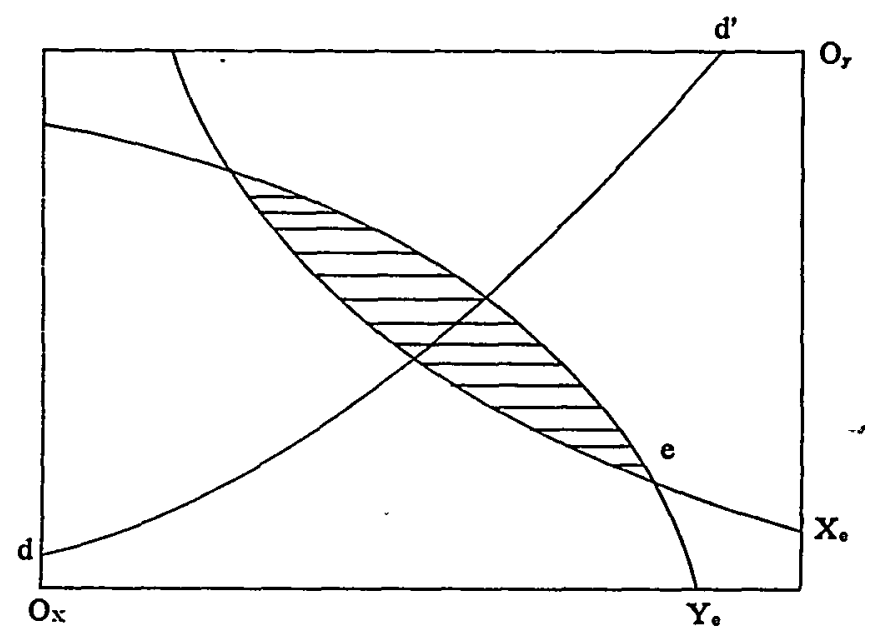

Figure 3

Assuming absence of transaction costs, knowledgeable pursuit by the parties of their own interests will dictate movement through trade from point a in figure 2 to a position on the segment of the contract curve bounded by $c$ and c'. Shifts to points southwest of $X_{1}$ or northeast of $Y_{1}$ are precluded to the extent that neither individual can be expected voluntarily to lower his own welfare; equilibrium off the contract curve (e.g., at e in figure 3) implies either imperfect information or irrational behavior, since both individuals could gain through further adjustment.

The ratio at which goods are exchanged is indicated by the slope of a straight line (called a price line) from point $a$ through the point the parties have reached by trade. Given a competitive market, equilibrium in figure 2 is possible only at $b$, the single point where indifference curves are simultaneously tangent to each other and to a price line. A price line drawn through any other point on the 
contract curve would cut the indifference curves through that point. A price yielding such a line would not clear the market, since equilibrium would require one individual to exchange beyond his preferred position and the other suboptimally to restrict his transactions. In figure 4, for example, assume the market price given by the line from a through $c$. Individual $X$ will then wish to trade only to point $f$, on indifference curve $X_{f}$, while $Y$ will consider point $f$, on indifference curye $Y_{f}$, ideal. At the established price, preferences dictate an excess demand for the first good equal to the vertical distance between $f$ and $f^{\prime}$ and an excess supply of the second good equal to the horizontal distance between $f$ and $f$. The resulting imbalances will induce a corrective shift in price, iricreasing the cost of the first good in terms of the second. Adjustment will continue until the price ratio associated with the line from a through $b$ in figure 2 is reached. Here $f$ becomes identical with $f^{\prime}$ and the supply of each good equals its demand. ${ }^{18}$

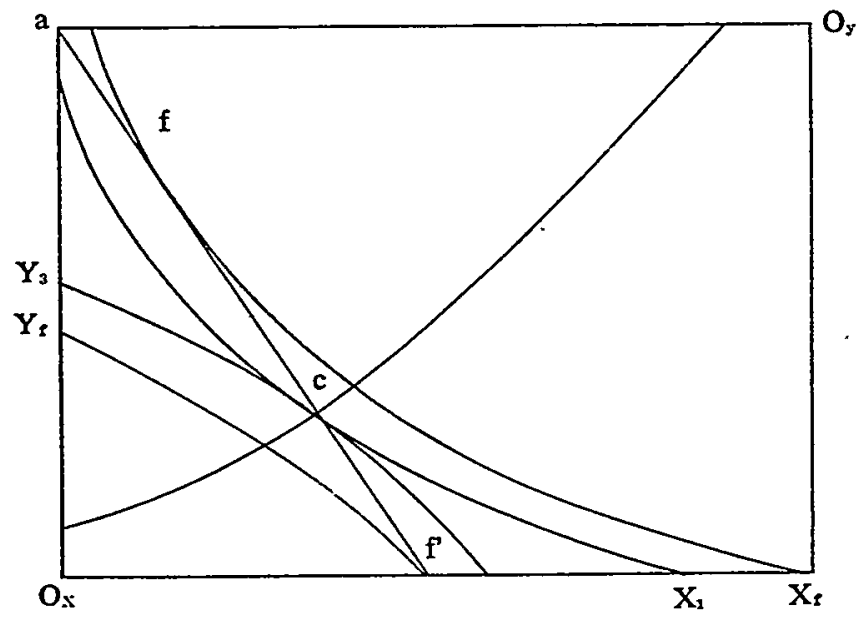

Figure 4

Under competitive conditions there is no incentive to either individual to accept a smaller gain from exchange than that yielded by point $b$ in figure 2, since by the definition of competition,

\footnotetext{
"The possibility of equilibrium at puint $b$ in figure $?$ has been recognized in the legal litcrature through equation of expectation and reliance interests when competition is assumed: "If we rest the legal argument for measuring damages by the expectancy on the ground that
} 
alternative opportunities for trade with others along line $a b$ would allow each to reach this position even if his prospective partner proves uncooperative. When each individual must remain at $a$ if agreement is not reached, however, distribution of the potential joint gain from contract formation is a function of relative bargaining strengths: Equilibrium may be achieved at any point on the contract curve from $c$ to c' consistent with the most advantageous exchange ratio the stronger party is able to demand. There remains a continuum of situations between the polar cases of perfect competition and bilateral monopoly, where the availability of alternative transactions guarantees one or both parties a minimum level of welfare beyond that associated with point $a$ but is insufficient to preclude joint loss from failure to contract. ${ }^{19}$

\section{Legal Implications}

The classic doctrines of contract law are largely the product of public commitment during the nineteenth century to ideological principles of individual autonomy and the free market:

The foundation of that system of law and morals was justice, the idea of human equality and of human liberty. Everyone was free to make such agreements as he thought fit with his fellow creatures, no one could oblige any man to make any agreement that he did not wish, but if a man made an agreement, the whole force of the State was brought to bear to compel its performance. It was a system in which there waś no place for privileges,--privileges for rank, or

this procedure offers the most satisfactory means of compensating the plaintiff for the loss of other opportunities to contract, it is clear that ... [i]t would be most forceful in a hypothetical society in which all values were available on the market and where all markets were "perfect" in the economic sense. In such a society . . . [t] the plaintiffs loss in roregoing to enter another contract would be identical with the expectation value of the contract he did make." Fuller \& Perdue, The Reliance Interest in Contract Damages: I, 46 YALE L.J. 52, 62 (1936).

"Fuller and Perdue note that "foregoing of other opportunities is involved to some extent in entering most contracts . ..." Id. at 60 . They state: "[T]he impossibility of subjecting this type of reliance to any kind of measurement may justify a categorical rule granting the value of the expectancy as the most effective way of compensating for such losses." Id. "The loss of bargain which the plaintiff sought to recover was evidently not the difference between the market value of the real estate and the contract price but was, instead, the difference between the selling price of stock (which the plaintiff had liquidated in order to make the purchase) at the time of the sale and the price of that stock at the time the plaintiff learned that the defendant did not have a good title to the real estate." Nordstrom, Toward a Law of Damages, 18 W. RES. L. REv.86, 99 (1966). 
wealth, or moral weakness. The general repeal of usury law was the crowning triumph of the system. ${ }^{20}$

The concomitant conclusion that "the reasons motivating private exchanges and the calculation of advantages to be secured thereby are left to individual determination"2t inevitably rests on assumptions difficult if not impossible to verify. Proponents of freedom of contract argue that personal preference functions more accurately reflect the components of individual welfare than estimates of needs made by outside observers. ${ }^{22}$ They urge reliance on self-interest as a more potent optimizing force than altruistic intervention: "lt is not from the benevolence of the butcher, the brewer, or the baker that we expect our dinner, but from their regard to their own interest. We address ourselves, not to their humanity but to their self-love, and never talk to them of our own necessities but of their advantages." 23 Although these assertions continue as premises of contract law, the freedom they defended as a "sacred thing," 24 never absolute, has been increasingly restricted as the Benthamite ideal proves largely illusory given the complexities of modern postindustrial society.

If the indifference curves in figure 2 are taken to represent objective indices of well-being rather than a tautological record of observed behavior, movement through exchange from point $a$ to a point southwest of $X_{1}$ or northeast of $Y_{1}$ is possible when either of the traders is unable accurately to estimate the value to him of a proposed transaction. Similar reasoning indicates that parties may reach a position such as e in figure 3 . Early unwillingness to presume substantial segments of society incompetent to safeguard their own interests ${ }^{2 s}$ has yielded to mounting evidence that

2o J. Gray, Preface to the Second Edition of Restraints on the Alienation of Property (2d ed. 1895), quoted in R. Hale, Freedom Through Law-Public Control of Private Governing Power 14 (1952).

"Dawson, Restitution or Damages? 20 Oнго St. L.J. 175, 190 (1959).

:2 "[T] he individual knows what is good for him. . . His own valuations are likely to be only an imperfect projection of what is good for him. But it is likely to be a closer approximation than an outsider can give... [T] [Te set of individual preferences becomes accepted as the arbiter of their own welfare." Rothenberg, Values and Value Theory in Economics, in The Structure of Economic Science 221, 240-41 (S. Krupp ed. 1966).

"A. SMith, AN INquiry into the Nature and Causes of the Wealth of Nations 14 (Modern Library ed. 1937).

24 H. Havighurst, The Nature of Private Contract 20 (1961).

$\because$ "The early law was not greatly concerned with whether one party to a contract held an 
[c]hoices may be made or consent given without adequate reflection or appreciation of the consequences; or in pursuit of merely transitory desires; or various predicaments when the judgment is likely to be clouded; or under inner psychological compulsion; or under pressure by others of a kind too subtle to be susceptible of proof in a law court. 26

Rules affording protection from the rigors of competition to obviously disadvantaged groups, such as the immature, have been extended; new criteria for relief, for example poverty, may be developing. ${ }^{27}$ The crudeness of such screening devices as "poverty" is probably justified by their ease of application.

That " $[t]$ here exist mutual gains from trade"28 has long been recognized: Nider, writing in the fifteenth century, asserted that "a concomitant of every contract is a certain factor of donation." 29 The law, although traditionally basing its support of contractual freedom in part on the existence of this possibility of joint benefit, largely refrained from controlling its allocation. The Restatement of Contracts provides: "[G]ain or advantage to the promisor or loss or disadvantage to the promisee, or the relative values of a promise and the consideration for it, do not affect the sufficiency of consideration." ${ }^{30}$ Such a rule would appear unnecessary when

undue advantage over the other. It made some ill-defined allowance for extreme youth; but as an indication of how uncertain this protection was, 1 may mention a fourteenth century case cited by Holdsworth in which a child twelve years of age was held bound on his own contract of service. Fraud and mistake were not recognized by the early common law courts as defenses, and it was apparently not until Chancery undertook to afford relief that there was any means of avoiding contracts made under such circumstances. Duress in the early law, moreover, if we are to believe Coke, was not a ground for refusing to perform a promise unless it took the form of a threat to kill or to maim." Id. at 6I-62.

${ }^{2} \mathrm{H}$. Hart, Law, Liberty, ANd Morality 33 (1963). "Bentham, as we know, held that every man is the best judge of his own interest. Taken as it stands, this simply isn't true." J. NARVESON, MoRaLITY AND UtILITy 84 (1967). "[T]here is the almost overwhelming weight of evidence . . . that people are often confused about their own feelings, do not know what they want, etc." Churchman, On the Intercomparison of Utilities, in THE Structurt of ECONOMIC SCIENCE 243, 25I-52 (S. Krupp ed. 1966).

${ }^{27}$ See, e.g. Sax \& Hiestand, Slumlordism as a Tort, 65 MiCH. L. Rev. 869 (1967); Blum \& Dunham, Slumlordism as a Tort-A Dissenting View, 66 Mich. L. REV. 451 (1968); Sax, Slumlordism as a Tort-A Brief Response, 66 Mich. L. REV. 465 (1968).

:* Buchanan, Positive Economics, Welfare Economics, and Political Econom!, 2 J. LAW \& ECON. I24, 137 (1959) (emphasis omitted).

29. Nider, ON the Contracts, OF Merchants 58 (C. Reeves transl., R. Shuman ed. 1966).

" Restatement of Contracts $\$ 8 I$ (1933). 
competitive forces dictate a single equilibrium such as point $b$ in figure 2. Where any position on the contract curve in figure 2 between $c$ and c' is possible, however, the argument for nonintervention instead of resting on the automaticity of joint benefit must rely on claims, no longer convincing, that contract law should be used to facilitate expression of market forces (e.g., bargaining power) but not to implement distribution policies. In the general case some scope for bargaining over transaction profits seems likely.

Certainly measures taken to move parties onto the contract curve can be more readily justified than actions which compel a shift along it: the former can result in gain to both traders, while the latter benefits one only at the cost of injury to the other. ${ }^{31}$ Nevertheless abstention, once the rule, has in many areas yielded to active control. Until recent decades, for example, the unregulated wage bargain was considered a bulwark of individual liberty and the most important consequence of movement from status to contract. ${ }^{32}$ Realization that market power rather than natural law determined division of gain between the parties ${ }^{3}$ led to abandonment of this attitude and removal of the relationship between employer and employee from the domain of general contract law. ${ }^{34}$ Bargaining strengths and the limits of permissible solutions were altered through governmental interference implementing political decisions concerning distribution

\footnotetext{
"Thus Adam Smith asserted: "To hurt in any degree the interest of any one order of citizens for no other purpose but to promote that of some other, is evidently contrary to that justice and equality of treatment which the sovereign owes to all the different orders of his subjects." A. SilitH, supra note 23, at 618. Nievertheless Voltaire defined government as "[a]n art consisting in taking as much money as possible from one class of citizens to give to the other." WebstrR's L'varkaID Dictionars 101 (L. Levinson ed. 1967).

"Like all other contracts, wages should be left to the fair and free competition of the market, and should never be controlled by the interference of the legislature." I D. Ricardo. Works AND Correspondexce 105 (P. Sraffa ed. 1951). "The right of a person to sell his labor upon such terms as he deems proper, is in its essence, the same as the right of the purchaser of labor to prescribe the conditions upon which he will accept such labor from the person offering to sell it. So the right of the employee to quit the service of the employer. for whatever reason. is the same as the right of the employer, for whatever reason, to dispense with the services of such employee . . . . In all such particulars the employer and the employee have equality of right, and any legislation that disturbs that equality is an arbitrary interference with the liberty of contract. which no government can legally justify in a free land." Adair $v$. United States, 208 U.S. 161. 174-75 (1908) (Harlan. J.).

(ritics of laisse7-faire ideology urged that "necessitous men are not. truly speaking. free men." Vernon ᄂ. Bethell. 28 Eng. Rep. 838.839 (Ch. 1761).

"Sue L. Frifdiay. Contract Law in America - a Social and Econonic Case Stldy (1965).
} 
of income. Contract intervention, however, is not limited to the labor market.

The Uniform Commercial Code states:

If the court as a matter of law finds the contract or any clause of the contract to have been unconscionable at the time it was made the court may refuse to enforce the contract, or it may enforce the remainder of the contract without the unconscionable clause, or it may so limit the application of any unconscionable clause as to avoid any unconscionable result. ${ }^{35}$

This provision is indicative of, and will itself stimulate, an increased willingness openly to assign judicial inquiry concerning agreement fairness a role in determining contract enforceability. ${ }^{36}$ Such scrutiny may permit relief from contractual obligations not only when commitment has left one party below his initial indifference curve but also when uneven distribution of agreement benefits results in equilibrium only marginally above $c$ or below c' in figure 2 . Today, to some extent, "we may look upon the law of contract as a number of rules according to which courts distribute gains and losses according to the equities. . . ."37

While it may once have been "required by moral law that the contracting parties, both seller and purchaser, neither believe nor have cause for believing that the contract being made is prejudicial to the community or commonwealth," 38 the contract is normally considered an instrument of individual advancement. ${ }^{39}$ Thus, "[t]he idea that the state on behalf of the community should intervene to dictate or alter terms of contracts in the public interest is, on the

"UNiform COMMERCIAL CODE $§ 2-302(1)$.

${ }^{36}$ See Williams v. Walker-Thomas Furniture Co., 350 F.2d 445 (D.C. Cir. 1965): American Home Improvement, Inc. v. Maclver, 105 N.H. 435, 201 A.2d 886 (1964); Lefr, Unconscionability and the Code-The Emperor's New Clause, I15 U.PA. L. Rev. 485 (1967).

"Cohen, The Basis of Contract, 46 HARv. L. Rev. 553, 584 (1933).

${ }^{38} \mathrm{~J}$. NiDer, supra note 29 , at 18 . "A contract has to be regarded as void, which, instead of aiming to be a means for just co-operation, endeavours to exploit the other members of the community by arbitrary demands of the members of the ring." R. StAMmier, THEORY of JUSTiCE 346 (I. Hussik transl. 1925).

39 "Its nature was to express and serve the immediate interests of bargaining parties. . . . [A]s a matter of law private individuals or groups were held quite strictly to their roles as private contractors or property owners. A litigant who claimed to vindicate a public interest might generally find standing in court only if he could show that his suit would likewise protect his special interest." J. Hurst, Law and the Conditions of Freedom in the NiNeteenth-Century United States 76 (1956). 
whole, alien to the classical theory of common law contract." 40 Nevertheless interference with freedom of contract is deemed justified when necessary to protect a community interest not represented by the parties to a transaction: The law declares certain bargains void as in violation of public policy.

\section{Application}

\section{Rationality Assumed}

As demonstrated in the last section, modern courts have been increasingly unwilling to maintain the fiction of classical theory that contracting individuals have negotiated an optimal equilibrium which it would be presumptuous to disturb. Intervention when the parties seem likely to be off the contract curve or outside the area between $X_{1}$ and $Y_{1}$ has become more frequent. In addition, solutions on the contract curve have sometimes been barred to prevent undue imbalance in the distribution of benefits or to protect a public interest external to the parties to an agreement. Judicial adjustment of obligations was virtually compelled by failure of the defendant to perform in both Groves and Peevyhouse. The courts selected one or two polar damage measures by weighing the equity of each in terms of gain or loss to the disputants. Conflicting conclusions demonstrate the need for more sophisticated analysis of the impact of alternative holdings on the individuals involved and suggest the existence of a more satisfactory intermediate solution.

Detailed representation in a two-dimensional box diagram of the positions of the parties in these cases is not possible. The problems left unresolved by both decisions can nevertheless be profitably studied in qualitative terms through application of geometric techniques. The resulting discussion should at least isolate unexpressed assumptions underlying the attitudes of the judges; it may also provide a basis for recommendation of an alternative solution.

In figure 5, position the defendants and the plaintiffs in each case as "X" and "Y" respectively. Thus movement along the contract curve in the direction of $\mathrm{O}_{y}$ benefits the defendant-lessees and injures the plaintiff-property owners. If the contracting parties were perfectly informed and bargained rationally, their agreements should

"Friedman, Changing Functions of Contract in the Common Law, 9 U. TORONTo L.J. I5, I8 (1951). 


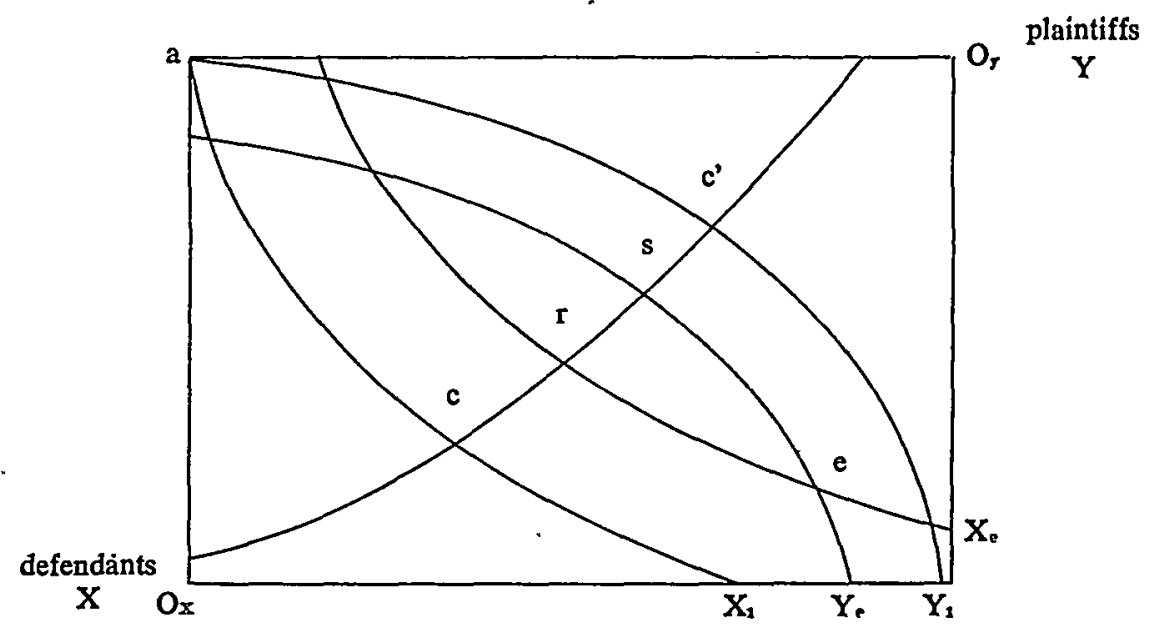

Figure 5

have moved them from point a, the situation before trade, to a position on the contract curve between $c$ and $c^{\prime}$, say point $r$. Then the value to the plaintiff-property owners of grading and other restorative operations must have equaled or exceeded the anticipated expense to the defendant-lessees which was accounted for in the contract price the defendants agreed to pay: otherwise the plaintiffs would not have included the provision requiring such work. That costs could have been underestimated is precluded by the informational assumption. If the possibility that the unfinished work could have been accomplished more cheaply while the gravel or coal was being removed is disregarded, the loss in money terms to the plaintiffs from default by the defendants must have amounted to at least $\$ 60,000$ in Groves" and $\$ 29,000$ in Peevy.house.

In these circumstances the rule in Groves would appear correct. Under that rule the plaintiff would obtain no more than the value to him of the performance for which he had bargained; any relief to the defendant would cause concomitant injury to the nonbreaching party. The result in Peevyhouse, presumably compelling movement

"Assuming perfect information and rational bargaining, the plaintiff-property owners in Groves must have understood that without the contract provisions requiring the restorative work. the defendant-lessees would have been prepared to pay $\$ 165,000$ for the lease the price actually paid, $S 105,000$, plus the cost of restoration. $\$ 60,000$ ). Therelore, the plaintilf-property owner in effect paid $\$ 60,000$ for the defendant-lessee's promise to perform the grading and restorative work. 
along the contract curve from $r$ to a point like s, which may lie beyond c', could be supported only by asserting that gains to the defendant from the shift will more than counterbalance the harm to the plaintiff. Such an argument, inevitably requiring interpersonal comparison of utilities, is not capable of objective verification or refutation. The unlikelihood of increasing community welfare through ulis transfer, however, may be simply demonstrated.

Postulate that utilities can be meaningfully compared. Measure gain in welfare to the defendant and the plaintiffs from the disputed transaction in standard utility units along the horizontal and vertical axes of figure 6. Let line $c_{1} r_{1}$ sc' indicate combinations of individual benefit levels associated with alternative allocations of joint gain from the contract before the court in Peevyhouse. Further assume that $r$ and $s$, corresponding to points $r_{1}$ and $s$ on the contract curve in figure 6 , respectively represent the position the parties would have occupied had the contract been performed and their position after breach by the defendant and consequent payment of $\$ 300$ in damages. Then pq, the benefit to the defendant from not performing the restorative work, exceeds $m_{1} n$, the loss to the plaintiff due to nonperformance. Thus, calculation of the cost of default as the diminution in the market value of the land should yield net social gain.

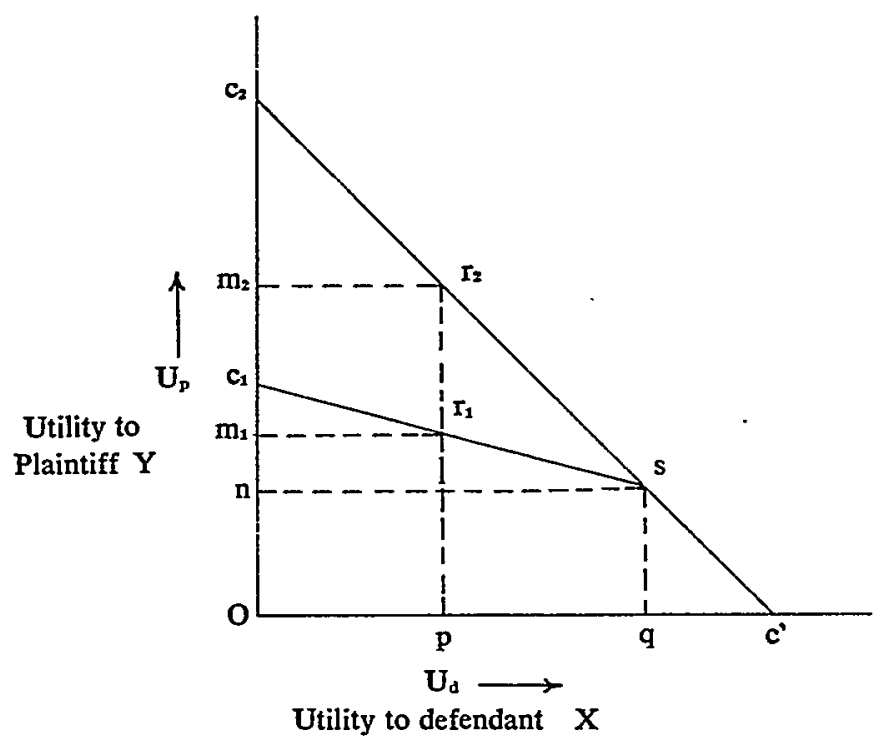

Figure 6 
Line $c_{1} r_{1} s c$, however, probably does not accurately indicate the possible combinations of utilities confronting the parties to the contract. It has been demonstrated that if point $r$ is on the contract curve, as assumed thus far in our discussion of figure 5 , the value of restorative operations to the plaintiffs must equal or exceed $\$ 29,000$. Hence loss to them in money terms as a result of the decision must amount to at least $\$ 28,700$. Gain to the defendant is $\$ 28,700$. That the utility of money to the farm owners is less than its worth to the mining company appears unlikely. If both claimants value money equally, $c_{1} r_{1} s c^{\prime}$ must be replaced by a line with at least the inclination of $\mathrm{c}_{2} \mathrm{r}_{2} \mathrm{sc}^{\prime}$, which cuts each axis at an angle of forty-five degrees and, therefore, represents equal utility from the same amount of dollars to each party. A slope having an absolute value equal to or greater than unity is required by the assumptions that the worth in dollars to the plaintiffs of performance by the defendants equals or exceeds its cost and that transfer of funds between the parties will benefit one exactly as much as it injures the other. This substitution precludes gain to the defendant, still pq, from exceeding loss to the plaintiffs, now $m_{2} n$. Judicial intervention to move the parties along the contract curvc from point $r$, the position reached by bargain, thus appears unwarranted.

\section{The Consequences of Inefficiency}

The premise that the parties had initially located on the contract curve, the basis of the preceding analysis, appears unwarranted. If restoration costs exceeded the value of such work to the plaintiffs, as seems likely, both parties could have profited by substituting payment of money by the defendant for the promised work. Since the possibility of mutual gain through alteration of the terms of a contract implies its nonoptimality, the agreements probably left the disputants at a point such as. e in figure 5 .

That change in market value may measure loss more accurately than cost of performance where the interest of the plaintiff in the property is primarily commercial is indicated by the subsequent history of the Groves dispute. Following the decision the defendant paid the plaintiff $\$ 55,000$ in settlement. The plaintiff did not immediately arrange performance of the work left undone, as might have been expected had its value to him equaled or exceeded its cost. The land remained unaltered until 1951, when a portion was leveled 
without removal of overburden. In 1953, fourteen years after the decision, about sixty percent of the property was sold for $\$ 45,000$. Leveling of the portion sold had cost approximately $\$ 6000 .{ }^{42} \mathrm{~A}$ similarly low utility to the plaintiffs was probably associated with performance in Peevyhouse, although here a possibility of personal attachment to what may have been a family homestead should not be disregarded.

Figure 5 demonstrates that when the position initially selected is off the contract curve, further movement can yield joint gain which may be allocated to either individual or shared by both. If transaction costs are assumed zero, a court may compel shift from point $\mathrm{e}$ to points $\mathrm{r}$ or $\mathrm{s}$ or any intermediate position without injuring either party. Opportunities of adjustment are more clearly indicated in figure 7 , where utility levels of the defendant and the plaintiffs in Peevyhouse are measured ordinally along the horizontal and vertical axes. In the preceding section interpersonal comparison of utility levels was assumed meaningful to permit evaluation of alternative outcomes through summation of gains and losses to the disputants. A similar postulate is unnecessary here. Only the sign of the slope of crss'c', the utility frontier indicating efficient combinations of individual benefit levels, is crucial to the present argument, and it is invariant with respect to changes of scale along the axes. Knowledge that movement along the utility frontier entails advantage to one party and injury to the other is sufficient.

As in figure 5, points $c$ and $c^{\prime}$ mark those limiting allocations of potential gain from the entire contract where benefit accrues to only one individual. Point e, off the contract curve in figure 5 , is inside the utility frontier in figure 7 for it represents agreement at a point where both individuals could benefit from further shift. Assume that the $\$ 300$ awarded by the court as damages for breach of contract adequately compensated the plaintiffs for their loss on the ground that the value to the plaintiff to be attained by inclusion of the restoration provision in the contract was the commercial value of the restored property after expiration of the lease. Then the decision may be thought of as having shifted the parties from point e to point $s$, a position on the utility frontier. Since the line es is horizontal, the mining company has been benefited without injury to the

\footnotetext{
ASee J. Dawson \& W. Harvey. Cases and Materials on Contracts and Contract REMEDIES 28 (1959).
} 
landowners. This follows because the commercial value of the restored property sought by the plaintiffs when contracting has been preserved by the award of $\$ 300$ while the defendant has been saved the expense of making the restoration. If the value of performance to the plaintiffs exceeded $\$ 300$, es must be replaced by a line such as es', indicating the consequent loss. Award of $\$ 29,000$, the cost of performance, would have established equilibrium at point $r$, benefiting the plaintiffs without harming the defendant. Any solution along the utility frontier between $r$ and $s$ permits gain to both parties, still assuming that resale value was the bargaining objective of the plaintiff. Points $r$ and $s$ in figure 7 correspond to similarly lettered positions in figure 5.

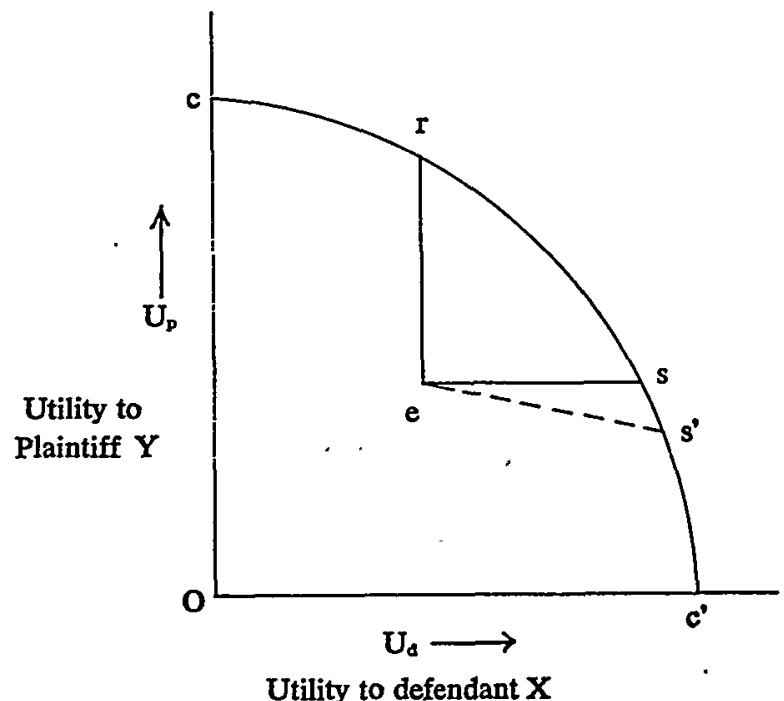

Figure 7

That the cost of performance exceeds its worth to the party who has sought it thus cannot compel limitation of recovery to the loss in market value resulting from breach. If compromise is considered an inexpedient departure from traditional solutions, the issue reduces to allocation of a windfall to one of the disputants. Had the court in Peevyhouse pushed analysis to this point it might well have followed 
Groves, reasoning, perhaps arbitrarily, that the innocent plaintiff rather than the willfully defaulting defendant should reap unanticipated benefit. 1ts decision appears in part a product of a mistaken assumption that granting a recovery more than sufficient to compensate for injury would in the case before it cause unjustifiable loss to the defendant. A proper concern, to avoid use of the damage remedy to punish willful breach of contract, seems thus to have been misapplied. Arguments of economic waste are largely spurious: The question is not whether unwanted work will be carried out. but how unexpected benefit will be distributed.

\section{Specific Performance}

The alternative of equitable relief is not generally available in situations such as those confronting the courts in Groves and Peevyhouse. Nevertheless, for either of two unrelated reasons, granting of specific performance may prove more satisfactory than application of any rule merely awarding damages.

First, as has been indicated, freedom of contract does not guarantee social efficiency even if perfect information and rationality are conceded. Community interests are not necessarily protected when individuals bargain for personal profit. In both cases under discussion, performance would probably have yielded a social return exceeding the benefit to the contracting parties: Statutes restricting strip mining operations or requiring restorative efforts following exploitation are evidence of public concern to prevent desecration of aesthetically attractive landscapes. ${ }^{43} \mathrm{~A}$ decree directing completion of the work, if obeyed, would increase community welfare when the sum of the resulting gains to the landowner and to individuals other than the contracting parties is greater than the expense of the required performance. Here again the values involved cannot be objectively

\footnotetext{
"See Annot., Statutory or Contractual Obligations to Restore Surface after Strip or Other Surface Mining, I A.L.R.2d 575 (1948); Brooks, Strip Mine Reclamation and Economic Inaly:is. 6 Natleral. Rissolrcis J. 13 (1966): Meiners. Sirip .Mining l.cgislaiion. 3 Natural. Resourcl:s J. 42 (1964). The landowner and the stripper frequently appear equally unresponsive to pleas of conservationists: "My conscience impels me, however, to place a goodly measure of blame for the eyesores of our countryside upon a group that has rarely been castigated - the landowners who have leased properties for stripping. Operators lusting for a quick prolit regardless of surface desecration have tound landow ners equally money-craving and more intent upon maximum coal royalties than upon restoration." Preresuing f.and ( PA. ANGl.fR 6 (March 1963), quoted in Meiners, supra at 467.
} 
verified. Moreover, compliance with the decree, even though in the public interest, would not be compelled by the fact of a subsequent compromise between the parties.

Second, where the cost of the work bargained for would exceed the associated benefit to the plaintiff, nonperformance yields a net gain which may be allocated to either or both of the parties to the contract. The extreme solutions reached in Groves and Peevyhouse, requiring movement from point $e$ in figures 5 and 7 to points $r$ and $s$, give all of the profit from readjustment to the plaintiff and the defendant respectively. Division of the gain, perhaps preferable, would probably follow an order of specific performance: the parties, left by the court at point $e$, would themselves normally negotiate a shift to that segment of the contract curve bounded by $\mathrm{r}$ and $\mathrm{s}$. Such an outcome, unlike the result in Peevyhouse, would assure full compensation of the innocent plaintiff, since he is always free to compel performance if offers of payment by the defendant are insufficient. Apportionment of the gain by the court itself, while reducing transaction costs, would risk undercompensation of the nonbreaching party. Freedom of contract is not confined to bargains for things the market judges commercially useful. The availability of the remedy of specific performance might permit achievement of the desired result without the expense of court action by encouraging one contemplating breach to bargain instead to adjust his duties.

\section{CONCLUSION}

As a general rule "where a party sustains a loss by reason of a breach of contract, he is, so far as money can do it, to be placed in the same situation, with respect to damages, as if the contract had been performed." Attempts to apply this standard damage measure in Groves and Peevyhouse yielded unsatisfactory solutions because the courts did not isolate and consciously guide the allocation of the unanticipated gains to the parties resulting from default by the defendants. The courts concerned themselves with ascertaining damages rather than allocating benefit. Parallel problems, similarly amenable to geometric analysis, arise under construction contracts as a consequence of unauthorized deviation from plans. More broadly, courts are often confronted with difficulties occasioned by

"Nobinson v. Harmon, 154 Eng. Rep. 363 (Ex. 1848). 
unexpected shifts in the profitability of agreements to the parties jointly. Failure to distinguish such changes from gains to one individual which are offset by losses to the other, a frequent error, for example, in cases where frustration or impossibility is urged, usually prevents adequate identification of the issues which should govern decisions. While allocation of benefit and injury in circumstances not provided for in the contract will continue to require application of subjective standards of justice, closer scrutiny of underlying economic realities can minimize the inevitable arbitrariness of such an approach. 
